\title{
STATUS OF SERUM ZINC LEVEL IN HYPOTHYROID PATIENTS WITH NORMAL SERUM ALBUMIN LEVEL: A CASE CONTROL STUDY
}

Dipesh Regmi, ${ }^{1}$ Narayan Gautam, ${ }^{2}$ Aakash Shahi, ${ }^{3}$ Sharad Bohara, ${ }^{4}$ Seema Subedi, ${ }^{5}$ Archana Jayan ${ }^{2}$

\begin{abstract}
INTRODUCTION

Decreased thyroid hormone synthesis and low levels of circulating thyroid hormones result in clinical hypothyroidism causing many metabolic processes to slow down. Zinc is essential for many biochemical processes and cell proliferation. Thyroid hormones influence Zinc metabolism by affecting absorption and excretion.
\end{abstract}

\section{MATERIAL AND METHODS}

This case-control study was conducted in subclinical hypothyroidism $(n=30)$, overt hypothyroidism $(n=30)$ and compared with age and sex matched euthyroid controls ( $\mathrm{n}=30)$ attending UCMS-TH. Serum free T3 (fT3), free T4 (fT4) and Thyroid Stimulating Hormone (TSH) were estimated by ELISA. The serum Zinc and Albumin were estimated by colorimetric Nitro-PAPS and BCG dye binding method respectively.

\section{RESULTS}

The overall frequency of Zinc deficiency has been observed 12 (40\%) in overt hypothyroidism, 9 (30\%) in subclinical hypothyroidism and two (6.66\%) in euthyroid controls. A significant association between serum Zinc with fT3, fT4 levels $(\mathrm{p}=0.0046)$ and with TSH level $(\mathrm{p}$-value $=0.030)$ was observed in all cases. The positive correlation of serum Zinc with fT3 level $(\mathrm{r}=0.217, \mathrm{p}=0.04)$, fT4 level $(\mathrm{r}=0.267, \mathrm{p}=0.011)$ while serum negative correlation with TSH level $(\mathrm{r}=-0.234$, $\mathrm{p}=0.026)$ and Albumin $(\mathrm{r}=-0.039, \mathrm{p}=0.713)$ were observed. The odds ratio shows 9.33 times Zinc deficiency likely to occur in overt hypothyroidism (CI: 1.86-46.68; p-value=0.0065) whereas 6.0 times in subclinical hypothyroidism (CI: 1.17-30.72; $\mathrm{p}$-value $=0.0315$ ) than euthyroid controls.

\section{CONCLUSION}

The significant difference in Zinc deficiency was observed in overt hypothyroid patients. However, non-significant difference in sub-clinical hypothyroidism as compared to euthyroid controls was found in all groups having normal albumin level. This may conclude that with progression of hypothyroidism there is significant decrease in Zinc with normal albumin. Hence, there is association between thyroid profile and serum Zinc status.

KEY WORDS Hypothyroidism, Serum Albumin, Serum Zinc, Thyroid profile, Thyroid disorder

1. Central Laboratory Service, Rapti Academy of Health Sciences, Dang, Nepal

2. Department of Biochemistry, Universal College of Medical Sciences, Bhairahawa, Nepal

3. Department of Medicine, Universal College of Medical Sciences, Bhairahawa, Nepal

4. Department of Biochemistry, Nepalgunj Medical College, Chisapani, Nepal

5. Nursing Staff, Niko Children Hospital and Research Center, Bharathpur, Chitwal, Nepal

DOI: http//doi.org/10.3126/jucms.v7i2.27135

For Correspondence

Narayan Gautam

Department of Biochemistry

Universal College of Medical Sciences

Bhairahawa, Nepal

Email:ng_bp22@yahoo.com 


\section{INTRODUCTION}

Zinc is extensively studied by bioinorganic chemistry and it is known that there are many metalloproteins with specific enzymatic activity containing zinc. ${ }^{1}$ It has been shown to influence hormones at several levels, including hormone secretion and activity and binding to the target tissue. Moreover hormones have been shown to influence trace element metabolism at several levels, including excretion and transport of trace element. ${ }^{5}$ Deficiency is usually due to decreased dietary intake or increased body loss of the metals. ${ }^{2}$ After binding with a specific nuclear receptor, $\mathrm{T}_{3} / \mathrm{T}_{4}$ induces transcription of genetic code via mRNA and regulates protein synthesis in most tissues. ${ }^{3}$ Decreased thyroid hormone synthesis and low levels of circulating thyroid hormones result in clinical hypothyroidism. This condition occurs more frequently in women; the overall incidences are about $3 \%$ of the general population. ${ }^{4}$ Hypothyroidism probably is initiated by autoimmunity against the thyroid gland in addition to different other causes. ${ }^{5}$ Symptoms of hypothyroidism include enlargement of thyroid gland also called goiter, mental retardation, low basal metabolic rate, increased risk of coronary heart diseases and different other symptoms. ${ }^{6}$ Subclinical hypothyroidism $(\mathrm{SCH})$ is defined as a thyroid stimulating hormone (TSH) serum level above the statistically defined upper limit of the reference range despite normal serum fT4 and fT3 concentration. ${ }^{7}$ This study aims to investigate the serum zinc level in hypothyroidism patients with normal serum albumin level.

\section{MATERIAL AND METHODS}

This study was carried from January 2017 to September 2017 in the Department of Biochemistry with collaboration of the Department of Internal Medicine at Universal College of Medical Sciences (UCMS), Bhairahawa, Nepal. The number of cases investigated comprised of subclinical hypothyroidism $(n=30)$, overt hypothyroidism $(n=30)$ and compared with age and sex matched euthyroid controls $(n=30)$. Blood samples were collected from all the participants of age group 18-80 years. Serum was separated and stored at $-20^{\circ} \mathrm{C}$ until evaluation. Free (fT3), fT4, TSH were estimated by ELISA using Diametra kits, Italy. The serum Zinc was estimated by colorimetric method (NitroPAPS method) and serum Albumin was estimated by BCG dye binding method. The consent was taken from each subject and the ethical approval for the study was provided by Institutional Review Committee with registration number UCMS/IRC/018/17.

\section{Diagnostic criteria for hypothyroidism}

As per the serum TSH profile, the thyroid disorders were classified as euthyroidism when the value of TSH within the normal range (0.3-6.16 mIU/l), subclinical hypothyroidism if serum TSH was high ( $>6.16 \mathrm{mIU} / \mathrm{l})$ but normal fT3 and fT4, and primary hypothyroidism, if serum TSH was $>6.16 \mathrm{mIU} / 1$ and increased fT3 and fT4.

\section{Data analysis}

All the data were analyzed by Statistical Package for Social Service (SPSS) for Window version; SPSS 20, Inc., Chicago, IL, USA. The other variables were expressed in terms of frequency $(\%)$, mean \pm standard deviation, and compared by ANOVA or Student's t-test wherever applicable. Correlation between fT3, fT4, TSH, Zn and Albumin was analyzed with Pearson's correlation coefficient. $\mathrm{P}<0.05$ was considered to be statistically significant.

\section{RESULTS}

The maximum frequency of Zinc deficiency $(<80 \mu \mathrm{g} / \mathrm{dL})$ was $12(40 \%)$ in overt hypothyroidism, $9(30 \%)$ in subclinical hypothyroidism and $2(6.67 \%)$ in euthyroid controls. While normal Zinc level (80-120 $\mu \mathrm{g} / \mathrm{dL})$ was observed in 25 (83.33\%) euthyroid, 19 (63.33\%) subclinical hypothyroidism and $16(53.33 \%)$ overt hypothyroidism. Moreover, Zinc excess $(>120 \mu \mathrm{g} / \mathrm{dL})$ was observed in $3(10 \%)$ euthyroid controls, $2(6.67 \%)$ each in subclinical hypothyroidism and overt hypothyroidism respectively. [Figure 1]

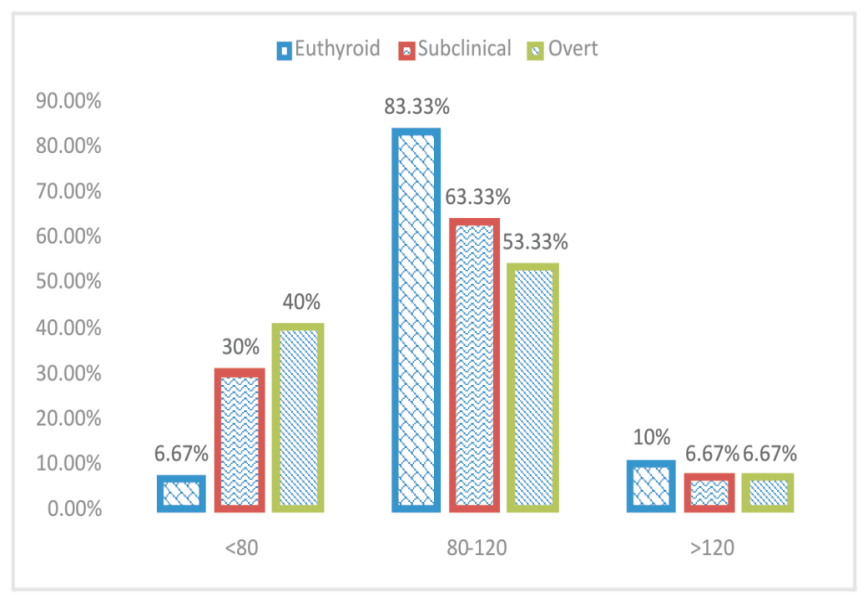

Figure 1. Zinc status in cases and controls based on serum Zinc group

There was no significant difference in mean age $(\mathrm{p}=0.127)$, Zinc $(\mathrm{p}=0.532)$ and Albumin $(\mathrm{p}=0.229)$ between subclinical hypothyroid and euthyroid controls. Higher BMI and serum TSH were observed and lower fT3 and fT4 were observed in subclinical hypothyroid as compared to euthyroid controls $(p=0.0001)$. Similarly, There was no significant difference in mean age $(p=0.913)$ and Albumin $(p=0.723)$ between overt hypothyroid and euthyroid controls. Higher BMI and serum 
TSH were observed $(\mathrm{p}=0.043, \mathrm{p}=0.0001)$, lower $\mathrm{fT} 3$, fT4 $(\mathrm{p}=0.0001)$ and low Zinc $(\mathrm{p}=0.036)$ were observed in overt hypothyroid as compared to euthyroid controls which were statistically significant. [ Table 1]

Table 1. Comparison of demographic and biochemical parameters in cases (subclinical and overt hypothyroidism) and controls (euthyroidism)

\begin{tabular}{lccccc}
\hline Variables & Euthyroidism & $\begin{array}{c}\text { Subclinical } \\
\text { hypothyroidism }\end{array}$ & p-value & $\begin{array}{c}\text { Overt } \\
\text { hypothyroidism }\end{array}$ & p-value \\
\hline Age $($ year $)$ & $34.60 \pm 13.04$ & $41.03 \pm 10.78$ & 0.127 & $35.93 \pm 14.01$ & 0.913 \\
Weight $(\mathrm{Kg})$ & $59.96 \pm 9.61$ & $64.93 \pm 6.92$ & 0.035 & $60 \pm 9.51$ & 0.929 \\
Height $(\mathrm{cm})$ & $1.58 \pm 0.061$ & $1.52 \pm 0.042$ & 0.0001 & $1.53 \pm 0.04$ & 0.001 \\
BMI $\left(\mathrm{kg} / \mathrm{m}^{2}\right)$ & $23.58 \pm 2.97$ & $27.79 \pm 2.48$ & 0.0001 & $25.48 \pm 3.47$ & 0.043 \\
fT3 $(\mathrm{pg} / \mathrm{ml})$ & $2.24 \pm 0.50$ & $1.83 \pm 0.43$ & 0.0001 & $1.02 \pm 1.6$ & 0.0001 \\
fT4 $(\mathrm{ng} / \mathrm{ml})$ & $1.57 \pm 0.35$ & $1.01 \pm 1.5$ & 0.0001 & $0.61 \pm 0.11$ & 0.0001 \\
TSH $(\mathrm{mIU} / \mathrm{l})$ & $2.32 \pm 1.14$ & $9.95 \pm 2.09$ & 0.0001 & $26.71 \pm 7.35$ & 0.0001 \\
Zinc $(\mu \mathrm{g} / \mathrm{dl})$ & $101.29 \pm 19.36$ & $93.13 \pm 31.06$ & 0.532 & $82.21 \pm 35.42$ & 0.036 \\
Albumin $(\mathrm{g} / \mathrm{dl})$ & $4.90 \pm 0.95$ & $4.52 \pm 0.67$ & 0.229 & $5.07 \pm 0.96$ & 0.723 \\
\hline
\end{tabular}

We observed that there were significant association of serum Zinc and TSH levels among euthyroidism, subclinical and overt hypothyroidism $(\mathrm{p}=0.030)$. The significant decrease in serum zinc level has been observed with increased in the TSH level. Similarly, there were significant association of serum Zinc and fT3, fT4 levels among euthyroidism, subclinical and overt hypothyroidism ( $\mathrm{p}=0.046)$. The significant increase in serum Zinc level has been observed with increased in the fT3 and fT4 level. [Table 2].

Table 2. Association between Zinc and TFT among euthyroidism $(n=30)$, subclinical $(n=30)$ and overt hypothyroidism $(n=30)$

\begin{tabular}{|c|c|c|c|c|c|}
\hline \multirow{3}{*}{$\begin{array}{l}\text { TSH } \\
(\mathrm{mIU} / \mathrm{L})\end{array}$} & \multicolumn{5}{|c|}{ Zinc $\mu \mathrm{g} / \mathrm{dL}($ Mean \pm S.D) } \\
\hline & Euthyroidism & Subclinical & Overt & Total & p-value \\
\hline & & Hypothyroidism & Hypothyroidism & $($ Mean \pm S.D $)$ & (ANOVA) \\
\hline $0.3-6.2$ & $\begin{array}{c}101.29 \pm 19.36 \\
(n=30)\end{array}$ & $(\mathrm{n}=0)$ & $\begin{array}{c}-- \\
(\mathrm{n}=0)\end{array}$ & $\begin{array}{c}101.29 \pm 19.36 \\
(\mathrm{n}=30)\end{array}$ & \\
\hline $6.21-10$ & $\begin{array}{c}-- \\
(\mathrm{n}=0)\end{array}$ & $\begin{array}{c}99.0 \pm 27.76 \\
(n=19)\end{array}$ & $\begin{array}{c}-- \\
(n=0)\end{array}$ & $\begin{array}{c}99.0 \pm 27.76 \\
\quad(n=19)\end{array}$ & \\
\hline $10.1-15$ & $\begin{array}{c}-- \\
(\mathrm{n}=0)\end{array}$ & $\begin{array}{c}83.0 \pm 35.10 \\
\quad(n=11)\end{array}$ & $\begin{array}{c}118.15 \pm 2.62 \\
\quad(\mathrm{n}=2)\end{array}$ & $\begin{array}{c}88.40 \pm 34.65 \\
\quad(\mathrm{n}=13)\end{array}$ & 0.030 \\
\hline$\geq 15$ & $\begin{array}{c}-- \\
(\mathrm{n}=0)\end{array}$ & $\begin{array}{c}-- \\
(n=0)\end{array}$ & $\begin{array}{c}79.64 \pm 35.27 \\
(\mathrm{n}=28)\end{array}$ & $\begin{array}{c}79.64 \pm 35.28 \\
(\mathrm{n}=28)\end{array}$ & \\
\hline fT3 & \multicolumn{5}{|c|}{ Zinc $\mu \mathrm{g} / \mathrm{dL}($ Mean \pm S.D $)$} \\
\hline $\begin{array}{l}(\mathrm{pg} / \mathrm{mL}) / \\
\mathrm{fT} 4(\mathrm{ng} / \mathrm{dL})\end{array}$ & Euthyroidism & $\begin{array}{c}\text { Subclinical } \\
\text { Hypothyroidism }\end{array}$ & $\begin{array}{c}\text { Overt } \\
\text { Hypothyroidism }\end{array}$ & $\begin{array}{c}\text { Total } \\
(\text { Mean } \pm \text { S.D) }\end{array}$ & $\begin{array}{c}\text { p-value } \\
\text { (ANOVA) }\end{array}$ \\
\hline$\leq 1.4 / \leq 0.8$ & -- & -- & $82.21 \pm 31.06$ & $82.21 \pm 31.06$ & \\
\hline $1.4-4.2 /$ & $101.29 \pm 19.36$ & -- & -- & $101.29 \pm 19.36$ & 0.046 \\
\hline $0.8-2.0$ & -- & $93.13 \pm 31.06$ & -- & $93.13 \pm 31.06$ & \\
\hline
\end{tabular}

The mean \pm SD of serum zinc level in overt hypothyroidism with low zinc level $(45.0 \pm 20.53 \mu \mathrm{g} / \mathrm{dL})$ and in overt hypothyroidism with normal/increased serum zinc level $(107.01 \pm 14.22 \mu \mathrm{g} / \mathrm{dL})$ is significantly different $(\mathrm{p}=0.0001)$. There was also significant difference between other variables like age, BMI, fT3, fT4, TSH and albumin. The mean \pm SD of serum zinc level in subclinical hypothyroidism with low zinc level $(53.56 \pm 25.88 \mu \mathrm{g} / \mathrm{dL})$ and in subclinical hypothyroidism with normal/increased serum zinc level (110.10 \pm $11.14 \mu \mathrm{g} / \mathrm{dL})$ is significantly different $(\mathrm{p}=0.001)$ whereas no significant difference between other variables like age, BMI, fT3, fT4, TSH and albumin. [Table 3]

Table 3. Comparison Mean \pm SD of study variables with decreased \& normal/increased serum Zinc level in overt $(n=30)$ and subclinical $(n=30)$ hypothyroidism

\begin{tabular}{lcccccc}
\hline Variables & Overt hypothyroidism & \multicolumn{3}{c}{ Sub clinical hypothyroidism } \\
\hline & $\begin{array}{c}\text { Decreased Zn } \\
(\mathrm{n}=12)\end{array}$ & $\begin{array}{c}\text { Normal/ } \\
\text { Increased Zn } \\
(\mathrm{n}=18)\end{array}$ & $\begin{array}{c}\text { p-value } \\
\text { A }\end{array}$ & $\begin{array}{c}\text { Decreased Zn } \\
(\mathrm{n}=9)\end{array}$ & $\begin{array}{c}\text { Normal } \\
\text { Increased Zn } \\
(\mathrm{n}=21)\end{array}$ & $\begin{array}{c}\text { p- } \\
\text { value }\end{array}$ \\
\hline Age & $33.17 \pm 14.04$ & $37.78 \pm 13.28$ & 0.002 & $39.67 \pm 12.14$ & $41.62 \pm 10.41$ & 0.982 \\
BMI & $24.61 \pm 3.96$ & $26.05 \pm 2.86$ & 0.0001 & $27.87 \pm 3.13$ & $27.76 \pm 2.23$ & 0.245 \\
fT3 & $1 \pm 0.132$ & $1.04 \pm 0.17$ & 0.0001 & $1.97 \pm 0.69$ & $1.77 \pm 0.26$ & 0.058 \\
fT4 & $0.64 \pm 0.094$ & $0.59 \pm 0.12$ & 0.0001 & $0.97 \pm 0.14$ & $1.02 \pm 0.15$ & 0.942 \\
TSH & $25.60 \pm 5.33$ & $27.45 \pm 8.17$ & 0.0001 & $9.51 \pm 2.25$ & $10.14 \pm 2.04$ & 0.938 \\
Zinc & $45 \pm 20.53$ & $107.01 \pm 14.22$ & 0.0001 & $53.56 \pm 25.88$ & $110.10 \pm 11.14$ & 0.001 \\
Albumin & $4.94+.90$ & $5.16 \pm 0.96$ & 0.0001 & $4.63 \pm 0.64$ & $4.48 \pm 0.70$ & 0.361 \\
\hline
\end{tabular}

There was positive correlation of serum Zinc with fT3 level $(\mathrm{r}=0.217, \mathrm{p}=0.04)$, fT4 level $(\mathrm{r}=0.267, \mathrm{p}=0.011)$, age $(\mathrm{r}=0.145, \mathrm{p}=0.172)$, BMI $(\mathrm{r}=0.025, \mathrm{p}=0.816)$. Serum Zinc was negatively correlated with TSH level $(\mathrm{r}=-0.234, \mathrm{p}=0.026)$ and Albumin $(r=0.039, \mathrm{p}=0.713)$. [Table 4]

Table 4. Pearson's correlation of serum Zinc with different parameters

\begin{tabular}{lcc}
\hline Variables & $\mathrm{R}$ & $\mathrm{p}$-value \\
\hline Age & 0.145 & 0.172 \\
BMI & 0.025 & 0.816 \\
fT3 & $0.217^{*}$ & 0.04 \\
fT4 & $0.267^{*}$ & 0.011 \\
TSH & $-0.234^{*}$ & 0.026 \\
Albumin & -0.039 & 0.713 \\
\hline
\end{tabular}

${ }^{*}$ p-value $<0.05$ was considered to be statistically significant There was strong association of Zinc deficiency between overt hypothyroidism and euthyroid controls with OR 9.33 (95\% CI=1.86 - 46.68; $\mathrm{p}=0.0065)$. Similarly, there was association of Zinc deficiency between subclinical hypothyroidism and euthyroid controls with OR $6(95 \%$ $\mathrm{CI}=1.17-30.72 ; \mathrm{p}=0.0315)$. [Table 5] 
Table 5. Odd ratio (OR) and association of zinc deficiency between overt and subclinical hypothyroidism as compared to euthyroid controls

\begin{tabular}{lccc}
\hline Zinc Level & Overt hypothyroidism & $\begin{array}{c}\text { Subclinical } \\
\text { hypothyroidism }\end{array}$ & Euthyroid controls \\
\hline Decreased & $12(\mathrm{a})$ & $9(\mathrm{a})$ & $02(\mathrm{~b})$ \\
Normal/Increased & $18(\mathrm{c})$ & $21(\mathrm{c})$ & $28(\mathrm{~d})$ \\
\hline
\end{tabular}

$\mathrm{OR}=\mathrm{a} * \mathrm{~d} / \mathrm{b} * \mathrm{c}=12 * 28 / 18 * 2=9.33(\mathrm{CI}: 1.86-46.68 ; \mathrm{p}$-value $=0.0065)$

OR $=a * d / b * c=9 * 28 / 21 * 2=6($ CI: 1.17- 30.72; p-value $=0.0315)$

\section{DISCUSSION}

In this study serum Zinc level in subclinical and euthyroid controls do not have significant difference $(\mathrm{p}=0.532)$, but with progression of disease when there was decrease in fT3 and fT4 and increased in TSH more than $10 \mathrm{mIU} / \mathrm{L}$, serum Zinc level in overt hypothyroidism decreases significantly as compared to euthyroid controls $(\mathrm{p}=0.036)$ which was in agreement with study done by Juboori ALAI et al. ${ }^{8}$

Thyroid transcription factors which are essential for modulation of gene expression contain Zinc at cysteine residues. ' Gongör et al in his study found a positive correlation between plasma T3 and Zn levels. ${ }^{10}$ Olivieri O et $\mathrm{al}^{11}$ showed that $\mathrm{Zn}$ deficiency has been led to decrease iodothyronine levels, and they also found a strong positive association between $\mathrm{Zn}$ and fT3 levels. Aktuna D et al stated that serum zinc levels in hyperthyroid patients were clearly higher than in the hypothyroid patients. ${ }^{12}$ Hampel $\mathrm{R}$ et al investigated that $\mathrm{Zn}$ deficiency has a synergistic effect on goiter formation. ${ }^{13}$ Another study showed that the concentration of $\mathrm{Zn}$ in sera of goiterous male and female patients was low before treatment as compared to control subjects. ${ }^{14}$

Similar results of Zinc deficiency were also found in the researches of Zhang et al and Kasim AK et al ${ }^{15-16}$. The most probable explanation is the link between endocrine functions with $\mathrm{Zn}$ deficiency which are altered in thyroid hormone metabolism and energy consumption. ${ }^{16}$ Yoshida $\mathrm{K}$ et $\mathrm{al}^{17}$ found decreased serum Zn levels in patients with hypothyroidism as compared to control subjects; he noted that gastrointestinal absorption of zinc is severely impaired in hypothyroidism subjects. An alternative explanation would be a change in zinc distribution; the low zinc level may reflect sequestration of zinc by the liver or other tissues. Another explanation also observed in the study of Bellisola $G$ et al is due to the significant influence of TSH in the variation of the concentration of iodine, selenium and zinc in normal and altered human thyroid tissues. ${ }^{18}$

Gupta RP et $\mathrm{al}^{19}$ and Hartoma RT et $\mathrm{al}^{20}$ who have reported that Zn deficiency could affect thyroid hormone synthesis and function. It was shown that $\mathrm{Zn}$ administration enhances the levels of T3 and T4 of hypothyroidism patients, while decrease the TSH levels. Nevertheless, the effects of Zinc on thyroid hormone levels and the thyroid gland in general are still not clear. Animal and human studies have yielded conflicting results, low T3 levels being found in some patients with zinc deficiency. ${ }^{21}$ Maxwell C and Volpe SL observed that the thyroid hormone levels and metabolic rates of two zincdeficient subjects were comparable, zinc supplementation (26.4 $\mathrm{mg}$ /day as zinc gluconate) increased both free and total $\mathrm{T} 3$ and T4 levels in one subject, but increased only total T3 in the other subject at four months, while resting metabolic rate was increased in both. ${ }^{22}$

Dhawan D et al and Pekary AE et al extracted that zinc has important roles in thyroid metabolism, it involves in T3 binding to its nuclear receptor, and participates in the formation and mechanism of action of TRH. ${ }^{23,24}$ Hence, the correlation between hypothyroidism and serum zinc is not a simple correlation and needs more specific studies. Zinc is transported in plasma bound to albumin and, to a lesser extent, $\alpha_{2}$ macroglobulin and oligopeptides. ${ }^{25}$ This study has shown that there is no significant difference of serum albumin, between subclinical, overt hypothyroidism and euthyroid controls.

There is clinical evidence suggesting that even mild thyroid dysfunction in the form of subclinical hypothyroidism is linked to significant changes in body weight and represents a risk factor for overweight and obesity. ${ }^{26}$ The current study reveals that there is significant difference of BMI, between subclinical, overt hypothyroidism and euthyroid controls. However, the correlation between BMI and Zinc deficiency has been observed statistically non-significant. The odds of having overt hypothyroidism is nine times greater than euthyroid healthy controls and six times greater in subclinical hypothyroidism indicating severity of disease increases as zinc deficiency become prominent.

Zinc has well established role in the gastrointestinal absorption, immune function and transcriptional regulation for the action of hormone in the body. The present study revealed that there is role of zinc in the hypothyroid state as shown by decreased zinc level compared to their peer control group. There is essentiality of zinc therapy to the hypothyroid patients for better recovery of its disease state which need to be undertaken with large number of sample with control randomized trial to establish the actual role of zinc supplement in the hypothyroid patients.

\section{CONCLUSION}

Hypothyroidism is a major health problem among adults. So factors that cause the hypothyroidism become the serious 
matter of concern and give idea to prevent this problem. With the limitation of short time period and small sample size, in our study, Zinc deficiency was observed significantly in overt hypothyroidism that concludes association between serum Zinc and hypothyroidism. However further studies are warranted to confirm our results that would explain the relationship between Zinc and hypothyroidism.

\section{ACKNOWLEDGEMENTS}

We would like to acknowledge the central laboratory service staffs, UCMS, Biochemistry for their constant support to accomplish this work.

\section{REFERENCES}

1. Bertini I, Drago R S, Luchinat C, (eds), Kluwer Boston Inc. Canada. Published by Riedel Publishing Company. NATO Advanced Study Institute, San Miniato-Italy, 1982; p 1-3.

2. Henkin RI. Trace metals in endocrinology. Med Clin North Am. 1976; 60: 779-97.

3. Kvicala J. and Zamrazil V. Effect of iodine and selenium upon thyroid function. Cent Eur J Public Health. 2003; 11(2): 107-13.

4. Standbury JB. and Kroc RL. Human Development and the Thyroid Gland: Relation to Endemic Cretinism, Plenum Press, New York, 2000; 19.

5. Wartofsky L. The scope and impact of thyroid disease. ClinChem. 1996; 42 (1): 121-4.

6. Surks MI and Ocampo E. Subclinical thyroid diseases. American Journal of Medicine. 1996; 100: 217-223

7. Grandone A, Santoro N, Coppola F, Calabrò P, Perrone L, De Giudice EM. Thyroid function derangement and childhood obesity: an Italian experience. BMC Endocr Disord. 2010; 10: 8.

8. Iham Amir Al Juboori, Rafi Al Rawi, Hussein Kadhem, A Hakeim, Estimation of Serum Copper, Manganese, Selenium, and Zinc in Hypothyroidism Patients. IUFS J of Biol. 2009; 68(2): 121-126.

9. Civitareale D, Saiardi A, Falasca P. Purification and characterization of thyroid transcription factor 2. Biochem. 1994; 304: 981-985

10. Güngör A, Bekir S, Müfide N, Salim B, Leyla Y, Halil Z. T3, T4, $\mathrm{TSH}, \mathrm{Zn}$ and copper metabolism in hyperthyroidism and hypothyroidism. Turk J Med Res. 1994; 12: 122-126.

11. Olivieri O, Girelli D, Stanzial AM, Rossi L, Bassi A, Corrocher R. Selenium, Zinc, and thyroid hormones in healthy subjects: low T3/T4 ratio in the elderly is related to impaired selenium status. Biol Trace Elem Res. 1996; 51(1): 31-41.

12. Aktuna D, Buchinger W, Langsteger W, Meister E, Sternad H, Lorenz O, Eber O. Beta-carotene, vitamin A and carrier proteins in thyroid diseases. Acta Med Austriaca. 1993; 20: 17-20.
13. Hampel R, Kühlberg T, Schneider KP, Glass A, Zöllner H. Serum zinc levels and goitre epidemiology in Germany. Z Ernahrungswiss. 1997; 36: 12-15.

14. Kandhro GA, Kazi TG, Afridi HI, Kazi N, Baig JA, Arain MB, Sirajuddin, Shah AQ, Sarfraz RA, Jamali MK, Syed N. Effect of zinc supplementation on the zinc level in serum and urine and their relation to thyroid hormone profile in male and female goitrous patients. Clin Nutr. 2009; 28: 162-168.

15. Zhang F, Liu N, Wang X, Zhu L, and Chai Z. Study of trace elements in blood of thyroid disorder subjects before and after 131I therapy. Biological Trace Element Research. 2004; 97 (2): 125-34.

16. Baltaci AK, Mogulkoc R, BelviranliM.Serum levels of Calcium, Selenium, Magnesium, Phosphorus, Chromium, Copper and Iron -their relation to zinc in rats with induced hypothyroidism. Acta Clinical Croatica .2013; 52(2): 151-156.

17. Yoshida K, Erythrocyte carbonic anhydrase I and zinc concentrations in thyrotoxicosis reflect integrated thyroid hormone levels over the previous few months. Rinsho Byori. 2007; 55: 560-565.

18. Bellisola G, Bratter P, Cinque G, Francia G, Galassini S, Gawlik $\mathrm{D}$, et al. The TSH-dependent variation of the essential elements iodine, selenium and zinc within human thyroid tissues Journal of Trace Elements in Medicine and Biology. 1998; 12(3):17782.

19. Gupta RP, Verma PC, Garg SL. Effect of experimental Zinc deficiency on thyroid gland in guinea-pigs.Annals of Nutrition and Metabolism. 1997; 41(6): 376-381.

20. Hartoma RT, Sotaniemi EA. Maattanen J. Effect of Zinc on some biochemical indices of mechanism. Nutrition and Metabolism. 1979; 23:294-300.

21. Arthur Jr, Beckett GJ. Thyroid function. British Medical Bulletin. 1999; 55(3): 658-668.

22. Maxwell C, Volpe SL. Effect of zinc supplementation on thyroid hormone function. A case study of two college females. Ann Nutr Metab. 2007; 51: 188-194.

23. Dhawan D, Singh BM, and Dani V. Zinc sulfate following the administration of iodine-131 on the regulation of thyroid functions, in rats. Hell Journal of Nuclear Medicine. 2007; 10(3):167-71.

24. Pekary AE, Lukaski HC, Mena I, and Hershman JM. Processing of TRH precursor peptides in rat brain and pituitary is Zinc dependent. Peptides. 1991; 12: 1025-32.

25. Cousins RJ. Zinc. In: Ziegler EE, Filer LJ, Jr, eds. Present knowledge in nutrition. 7th ed. Washington, DC, USA: International Life Sciences Institute Press. 1996: 293-306.

26. Danforth E, Jr, Horton ES, O'Connell M, Sims EA, Burger AG, Ingbar SH, et al. Dietary-induced alterations in thyroid hormone metabolism during over nutrition. J Clin Invest. 1979; 64: 133647. 